\title{
Újratermelődő „gettók”? - A helyi fejlesztés lehetőségei és korlátai egy szélsőségesen marginalizált kistelepülésen
}

\section{Reproducing "ghettos"? - Development in a village undergoing advanced peripheralisation}

\author{
MIHÁLY MELINDA
}

MIHÁLY Melinda: tudományos segédmunkatárs, Közgazdaság- és Regionális Tudományi Kutatóközpont, Regionális Kutatások Intézete; 5600 Békéscsaba, Szabó Dezső u. 42.; mihaly.melinda@krtk.mta.hu; https://orcid.org/0000-0003-4436-5282

KULCSSZAVAK: helyi fejlesztés; gettósodás; autonómia; képessé tétel; társadalmi-térbeli marginalizáció; „ellenállás tere”

ABSZTRAKT: A szélsőséges társadalmi-térbeli marginalizáció eredményeként a társadalmilag kirekesztett csoportok területileg is koncentrálódnak, vidéki „gettókba” „záródnak". A szegregátumokban kialakuló, a többségi társadalomtól elzárt párhuzamos intézményrendszer (pl. szegregált iskola, óvoda, illegális bolt, közmunka) tovább nehezíti a helyiek számára a marginalizált helyzetből, terekből való kitörést. Ha a (társadalmi) teret Lefebvre nyomán a cselekvés forrásának is tekintjük, akkor a gettósodó kistelepülések lakóit is képesnek kell tekintenünk arra, hogy tevőlegesen alakítsák a helyzetüket. A szélsőségesen marginalizált teret Henri Lefebvre és Edward Soja után „az ellenállás terének" is tekintem. A helyi szereplők cselekvőképességét elméletileg az autonómia egyéni, kollektív és szervezeti (politikai) értelmezéseivel igyekszem megragadni, empirikusan pedig etnografikus módszerekkel. Az esettanulmányomként szolgáló gettósodó településen létrejött civilalapú helyi fejlesztés megmutatta, hogy a strukturális elnyomás ellenére a szélsőségesen marginalizált csoportoknak is van cselekvő ereje. Azonban éppen a strukturális elnyomás miatt van külső segítségre szüksége a gettósodó falvakba záródott lakosságnak a helyi fejlesztés során. A helyi fejlesztést a hatalmi egyenlőtlenségek kontextusában értelmezem. A hatalmi egyenlőtlenségek megjelennek a fejlesztő szervezet és az állam viszonyában, a helyi fejlesztés döntéshozatalában is leképeződő centrum-periféria viszonyokban (kistelepülés és főváros, helyi elit és marginalizált helyiek), beleértve a fejlesztő szervezet és a fejlesztés „kedvezményezettjei” közti hatalmi egyenlőtlenségeket. A patriarchális és rasszizáló struktúrák leépítése érdekében fontos, hogy az alapítvány nem roma munkatársai is reflektáljanak „fehér privilégiumaikra”(,white privilege”) és a társadalmi nemükből adódó kiváltságaikra. A helyi fejlesztés intézményi kereteit illetően Magyarországon egyre inkább az állami kontroll és klientalizmus határozza meg a civilek és az állam viszonyát. Ennek következtében a szakpolitikákkal és az intézményrendszerrel szembeni kritikát megfogalmazó civilek számára egyre nehezebbé válik a pénzügyi erőforrásokhoz való hozzáférés.

Melinda MIHÁLY: junior research fellow, Institute for Regional Studies, Centre for Economic and Regional Studies; Szabó Dezső u. 42., H-5600 Békéscsaba, Hungary; mihaly.melinda@krtk.mta.hu; https://orcid.org/0000-0003-4436-5282

KEYWORDS: local development; ghettoisation, autonomy; empowerment; socio-spatial marginalisation; spaces of resistance

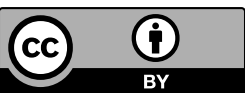


ABSTRACT: High socio-spatial marginalisation has the consequence that socially excluded people and groups are spatially concentrated (spatialisation according to Vincze), or in other words "locked-up" in "rural ghettos". Socio-spatial marginalisation has an ethnic dimension. The institutional system of ghettos sealed off by the mainstream society and existing in parallel (e.g. separate schools, illegal shops, public work) prevents locals from breaking out of their ghettoisation.

If we regard (social) space as a space for action, we must go beyond the idea that people in villages live as powerless victims of ghettoisation. Based on the works of Henri Lefebvre and Edward Soja, I consider spaces that are in an advanced state of peripheralisation (advanced peripheralisation, advanced socio-spatial marginalisation or ghettoisation) as "spaces of resistance". I characterise local agency theoretically in terms of their individual, collective and organisational (political) autonomy and, empirically, through ethnographic methods.

The case study of a civic local development initiative in a ghettoised village showed that individuals and groups have an agency despite advanced marginalisation and structural oppression. Due to structural oppression, however, they need outside help (local development).

Local development can be interpreted in the context of power asymmetries. Power asymmetries characterise multiple relationships: between development organisations and the state, between the various decision-makers involved in local development (centre-periphery relationships typical of the relationship between small settlements and the capital or local elite and marginalised locals). However, power asymmetries also exist between the development organisation and the "beneficiaries".

In order to deconstruct patriarchal and racialising structures within which development organisations and their "beneficiaries" exist, it is important that the members of the development organisation are aware of their "white privilege" or gender-specific advantage. As far as the relationship between state and development organisations is concerned, state control and clientelism increasingly determine the relationship between the state and civil society. As a result, it is becoming increasingly difficult for those civil organisations that formulate criticisms of social policy or the institutional system to gain access to financial resources.

\section{Bevezetés}

A regionális egyenlőtlenségek növekedése globális tendencia, ez alól Magyarország sem kivétel. A zsáktelepülések és az aprófalvak periferizálódása már a szocializmusban megkezdődött (Bajmócy, Józsa, Pócsi 2007), a rendszerváltás után azonban tovább folytatódott, és a folyamatot Magyarország EU-hoz való csatlakozása sem törte meg (Timár 2007). A hazai településfejlődés végletes történeti egyenlőtlenségeinek eredményeként a 2000-es évekre szükségessé vált az aprófalvakat (is) érintő szélsőséges társadalmi-térbeli marginalizáció (gettósodás) folyamatának megértése (Váradi, Virág 2015; Virág 2010).

A szélsőséges marginalizáció vagy más néven gettósodás (Váradi, Virág 2015) olyan társadalmi-térbeli folyamat, amelynek eredményeként a tásradalmilag kirekesztett csoportok strukturálisan hátrányos helyzetü (,structurally disadvantaged”) terekbe „szorulnak” (Mihály 2019a, b). A szegregátumokban kialakuló, a többségi társadalomtól elzárt párhuzamos intézményrendszer (pl. szegregált iskola, óvoda, illegális bolt, közmunka) tovább nehezíti a helyiek számára a marginalizált helyzetből, terekből való kitörést. Ha a (társadalmi) teret a cselek- 
vés forrásának is tekintjük (Lefebvre 1991 [1974]), akkor a gettósodó kistelepülések lakóit is képesnek kell tekintenünk arra, hogy tevőlegesen alakítsák a helyzetüket (Mihály 2019a). A szélsőségesen marginalizált teret Henri Lefebvre és Edward Soja után „az ellenállás terének” is tekintem. A helyi szereplők cselekvőképességét az autonómia egyéni, kollektív és szervezeti értelmezéseivel igyekszem megragadni.

Az elméleti keretezést követően a kutatásom módszertanával kapcsolatos reflexióimra térek ki. Szó lesz a fogalomhasználathoz kapcsolódó dilemmáimról és a kutatásban alkalmazott kritikai realista etnográfiáról. Esettanulmányként egy szélsőségesen marginalizált települést, Tarnótot választottam, ahol az Egyenlőség Alapítvány helyi fejlesztési projektet szervezett. A kutatásban alkalmazott résztvevő megfigyelés, dokumentumelemzés és a félig strukturált interjúk abban segítettek, hogy több szempontból (az alapítvány munkatársai, helyi lakosok, kedvezményezettek) ismerjem meg a helyi fejlesztési kezdeményezést. Kutatásetikai okoból a település, a helyi kezdeményezés és az összes érintett nevét megváltoztattam.

Az aprófalvakban történő gettósodás intézményi kereteinek felvázolása után a helyiek egyéni stratégiáit az intézményrendszer és a szakpolitikák kontextusában értelmezem. A helyben elérhető oktatás és a munka sokszor újratermeli a marginalizációt és sérti a helyi cselekvők egyéni autonómiáját. A tarnóti tapasztalatok megmutatják, hogy milyen egyéni stratégiák alakulhatnak ki válaszul a strukturális egyenlőtlenségekre, és hogy ezek a stratégiák mennyiben termelhetik újra a helyiek marginalizált helyzetét, marginalizált tereit és ezáltal hogyan hatnak a helyiek egyéni és kollektív autonómiájára.

Az egyéni stratégiákon túl, a tarnóti terepen lehetőség nyílt a helyiek közös stratégiáinak vizsgálatára is. Mivel a helyiek mozgásterét meghatározza az intézményrendszer, ezért először azt tekintettem át, hogy az állam hogyan alakította a civilek és a helyi lakosok azon lehetőségét, amellyel ők maguk képessé válnának a térbeli egyenlőtlenségek negatív következményeinek mérséklésére (szervezeti autonómia). A marginalizált csoportok számára sokszor nehézséget jelent a tágabb értelemben vett politikai döntéshozatalban való részvétel, mivel ennek lehetőségétől a kulturális, oktatási, nyelvi és fizikai korlátok is elzárják őket (Amin, Cameron, Hudson 2002). Ezeknek a korlátoknak egy része tudatos fejlesztéssel leépíthető. Az egyéni és kollektív autonómia fejlesztéséhez fontos, hogy tudatossá váljon a nemi vagy etnikai alapon történő strukturális elnyomás. Ezért az esettanulmányban azt is vizsgálom, hogy erre a helyzetre milyen módon válaszol az Egyenlőség Alapítvány. A helyi kezdeményezésekben alkalmazott döntéshozatalban potenciálisan fejleszthetők a marginalizált csoportok demokratikus részvételéhez szükséges készségei. Ebből a szempontból vizsgálom a döntéshozatal módját az Egyenlőség Alapítvány tarnóti fejlesztési projektjében (egyéni és kollektív autonómia). A helyi stratégiák elemzésére építve tehát azt a kérdést járom körbe, hogy figyelembe véve az intézményi korlátokat, milyen módon lehet kiutat találni a gettósodásból. 


\section{A gettósodó vidéki terek mint az „ellenállás terei”}

Lefebvre (1991 [1974]) elmélete szerint a (társadalmi) tér, így a gettósodó tér is tekinthető a cselekvés forrásának, azaz a hatalommal szembeni „ellenállás terének” (Soja 1999). Soja harmadik tere, a megélt tér ('́gy az „ellenállás tere” is), az a tér, amelyben az embereknek lehetőségük nyílik szembe szállni a hatalommal, amely mind az első térben (azaz az épített környezetben), mind a második térben (a mindenkori hatalom által formált és irányított tér) is markánsan jelen van (Berki 2015).

\section{A gettósodó vidéki terek, a szélsőséges társadalmi-térbeli marginalizáció színterei}

A szélsőséges társadalmi-térbeli marginalizáció eredményeként a társadalmilag kirekesztett csoportok területileg is koncentrálódnak, vidéki „gettókba” „záródnak" (Mihály 2019a). A szélsőségesen marginalizált terekben párhuzamosan létező intézményrendszer (pl. szegregált iskola, óvoda, illegális bolt) segíti a többségi társadalom és a társadalmilag kirekesztett csoportok elkülönülését (Szalai 2002). A gettósodó falvakban élö emberek társadalmilag és területileg is olyan távol kerülnek más társadalmi rétegektől, hogy a "gettóból” való elmozdulás ténylegesen és szimbolikusan is lehetetlenné válik (Ladányi et al. 2004; Váradi, Virág 2015).

A társadalmi-térbeli marginalizációnak van etnikai dimenziója is, hiszen a romák felülreprezentáltak a gettósodó területeken (Vincze 2014a). Vincze Enikő (2014b, 2019) a rasszizálódás és a romák „gettókba záródása” közötti kapcsolatra mutat rá. A rasszizálódást ${ }^{1}$ Kóczé (2016b) olyan folyamatnak tekinti, amelyben a különböző testi jegyek alapján hátrányosan megkülönböztetnek személyeket és csoportokat. A romák „segélyből élőként” történő megbélyegzése a szegénység rasszizálásának tekinthető (Vincze 2014b). A rasszizálás ebben az értelemben arra a gyakorlatra utal, amikor a romát, mint „más rasszhoz/etnikumhoz tartozót” (,racial other”) társítják a „,szegénnyel”, és a „roma szegénységet” olyan „természetes folyamatként” értelmezik, amelynek eredményeként az „alsóbbrendű rassz/etnikum” a premodern („nem civilizált”) csapdában ragad. A szegénység rasszizálásaként a szegény romákat kirekesztik a „fejlett” városokból és országokból, olyan „elmaradó” területekbe szorítva őket, amelyekben az anyagi depriváció (az anyagi javaktól való megfosztottság), a függőség és megaláztatás újratermelődik. Ezek a helyek radikálisan csökkentik a szélesebb körü társadalmi életben való részvételt és fenntartják a kizsákmányoló és fegyelmező-ellenőrző viszonyrendszereket (Vincze 2014b).

A gettósodás során a nemkívánatosnak tartott lakosságot nem csak „fejletlen” (,underdeveloped”) területekre „szorítják” vissza. A gettósodó területek arra is szolgálnak, hogy a hatalmon lévők kontrollt gyakoroljanak a „gettókba” szorított lakosság felett, és ha szükséges, olcsó informális munkaerőként vagy politikai 
szavazóbázisként használják ki őket. A „gettókban” élő lakosságot rasszizálva azért teszik felelőssé, mert a vélt egyéni, természetes vagy kulturális hiányosságuk miatt „feketemunkában vesznek részt”, „segélyekből élnek” és „bűncselekményt követnek el" (Vincze 2019). A gettósodó területeken a szegénység folyamatosan újratermelődik, nyomorrá alakul át. A helyiek képtelenné válnak arra, hogy hosszú távon tervezzenek, hiszen a mindennapi túlélés felemészti az összes energiájukat (Ladányi, Szelényi 2004; Durst 2008, idézi Váradi, Virág 2015, 103.). A gettósodó területekbe „szorult” lakosság azonban ebben a közegben is képessé válhat arra, hogy tevőlegesen alakítsa a helyzetét. A helyi szereplők cselekvőképességét az autonómia egyéni, kollektív és szervezeti értelmezéseivel igyekszem megragadni.

\section{Alternatív autonómia koncepciók: hogyan válhatnak a gettósodó vidéki terek az „ellenállás tereivé"?}

Egyéni autonómia. Szemben az autonómia libertáriánus megközelítésével - amely az egyén felelősségét hangsúlyozza és vak a strukturális elnyomás mechanizmusaira - az autonómiát a relacionális elméletekből kiindulva definiálom. Az autonómia a relacionális megközelítésben nemcsak kapacitás/képesség (capacity), hanem állapot (status) fogalom is (Mackenzie 2014a). Az autonómia státusz és képesség dimenziói összefüggnek egymással. Mackenzie szerint a társadalmi elismerés hiánya csökkenti az egyén képességét arra, hogy bízzon saját magában, vagyis, ha egy egyént nem ismer el a társadalom bizonyos szerepekben, akkor az alááshatja az egyén önmagáról mint autonóm szereplőről alkotott képét. Ahhoz, hogy valaki független (self-determining) életet élhessen, nemcsak képességekre és lehetőségekre van szüksége, hanem arra is, hogy ő önmagát és a társadalom is őt autonóm cselekvőnek tekintse (státusz) (Mackenzie 2014a). Az önálló cselekvőként való elismerés hiánya igen jellemző a dominancia és az egyenlőtlen hatalmi viszonyok esetén, különösen akkor, amikor e viszonyok a társadalmi nemhez, rasszhoz, etnicitáshoz és a fogyatékkal éléshez kapcsolódnak (Mackenzie 2014a). A társadalmi igazságosságból adódó morális kötelesség, hogy az egyének marginalizált helyzetére autonómiájuk fejlesztésével reagáljunk (Mackenzie 2014b). A sebezhető/marginalizált csoportok megerősítését a képességszemlélet segítheti. A képességszemléletben a marginalizált csoportok is cselekvőként jelennek meg (Sen 1999). A cselekvőképességet azonban fel kell építeni, hiszen „a társadalmi környezet és a társadalmi, politikai és jogi intézményrendszer segítheti vagy korlátozhatja az egyén szabadságát" (Mackenzie 2014a, 51.). Fontos, hogy a helyi fejlesztési projektek a helyiek stratégiáira építsenek, és a képességszemlélet alapján támogassák őket abban, hogy változtassák meg a saját helyzetüket és éljenek a lehetőségeikkel (Gébert et al. 2016).

A kollektív autonómia összefonódik a tágabb értelemben vett politikával és politizálással (politika mint a közügyekről való véleményformálás). Cornelius Castoriadis szerint a kollektív autonómia nemcsak a törvények megalkotásáról 
szól, hanem - ahogyan azt Serge Latouche (a nemnövekedés mozgalom egyik kiemelkedő gondolkodója) megfogalmazza - ugyanennyire fontos, hogy a társadalom képes legyen folyamatosan megkérdőjelezni ezeket a törvényeket és szabályokat (Asara, Profumi, Kallis 2013). Ennek értelmében a politizálás értelmezhető a kollektív autonómia termékeként is, mivel az ideális intézményeket explicit módon kérdőjelezi meg. Castoriadis a társadalom önszerveződésre való képességét tekinti demokráciának, azaz azt a társadalmi berendezkedést, amely lehetővé teszi a döntéshozatalban való közvetlen részvételt (Asara, Profumi, Kallis 2013).

Szervezeti (politikai) autonómia. Összhangban az autonómia relacionális megközelítésével a társadalmi vállalkozást kutatók egy jelentős csoportja azt vallja, hogy a társadalmi vállalkozásoknak akkor is meg kellene tudniuk őrizni a szervezeti (politikai) autonómiájukat, ha állami, alapítványi vagy egyházi támogatást kapnak. Coraggio és szerzőtársai (2015) szerint a szociális és szolidáris gazdaság kezdeményezéseinek nem lenne szabad a kormányzati programok vagy a magánalapítványok egyszerü végrehajtóivá válniuk. A létező intézményi keretek azonban befolyásolják, hogy egy társadalmi vállalkozás milyen mértékben képes megőrizni szervezeti autonómiáját.

A helyi fejlesztésben fontos az egyén szintjén elismerni a helyi fejlesztés „kedvezményezettjeinek” autonómiáját (státusz), ezen felül reflektálni azokra a strukturális mechanizmusokra, amelyek az egyéni autonómiakapacitást vagy cselekvőképességet korlátozhatják. A helyi fejlesztés értelmezhető olyan politikai folyamatként, amelynek célja a helyiek kollektív autonómiájának, azaz az önszerveződésre való képességének és a közügyekkel kapcsolatos véleményformálásának fejlesztése. A helyi fejlesztést megvalósító szervezetek szempontjából ki kell emelni a szervezeti (politikai) autonómia fontosságát, amit a helyi fejlesztés intézményrendszere tud biztosítani.

A „gettókból” elérhető intézményrendszer (pl. iskola, munka) negatívan hat az egyéni autonómia kapacitás és státusz dimenzióira. Azonban a gettósodó vidéki terek is az „ellenállás tereivé” alakíthatóak a helyi fejlesztés olyan kezdeményezéseivel, amelyek reflektálnak a nemi vagy etnikai alapú strukturális elnyomásra.

\section{Módszertani reflexiók}

Tudatában vagyok a „gettó” és „gettósodás” kifejezés stigmatizáló hatásának és különböző jelentéstartalmainak - amelyek mást jelentenek az Egyesült Államokban, ahol a fogalomhasználat gyökerezik -, mégis használom e kifejezést, mert alkalmas a társadalmi és területi mobilitást akadályozó etnikai alapú térbeli izoláció megragadására (Kóczé 2011). A gettósodás szinonimája a szélsőséges marginalizáció, melyet egyaránt tekintek területi és társadalmi folyamatnak (Nagy et al. 2015). A gettósodást a térben kiterjesztve, olyan folyamatnak értelmezem, amely nem kizárólag városokban valósulhat meg, hanem akár aprófalvakat is érinthet. 
Egy gettósodó aprófaluban lezajló helyi kezdeményezés példáján igyekszem megérteni, hogyan alakíthatóak a gettósodó vidéki terek az „ellenállás tereivé”. A kutatást kritikai realista megközelítéssel és etnografikus módszerekkel végeztem. A kritikai realista megközelítés (Bhaskar 1989a, 1989b) lehetővé teszi, hogy a struktúra-ágencia viszonyára fókuszáljak, azaz hogy a helyiek cselekvőképességének lehetőségeit a marginalizált helyzetet és teret termelő strukturális folyamatokra reflektálva vizsgáljam. Az etnografikus módszerek (résztvevo" megfigyelés, félig strukturált interjúk ${ }^{3}$ és dokumentumelemzés) abban segítettek, hogy a helyi lakosok és a civil szervezet perspektíváján keresztül érthessem meg a marginalitást és az autonómiát befolyásoló strukturális folyamatokat.

Tarnót szélsőségesen marginalizált (gettósodó) település az Észak-Alföldön, ahol egy politikailag független civil szervezet, az Egyenlőség Alapítvány - amelynek az eredeti profilja a művészetalapú oktatás - komplex fejlesztési programot indított 2009-ben. Tarnótot az alapítvány tudatosan választotta annak érdekében, hogy bebizonyítsa, hogy képességszemléletű egyéni és közösségfejlesztéssel még a leghátrányosabb helyzetű falvak felzárkóztatása is megvalósítható. Az alapítvány 2016-ban állandó munkát biztosított 7 tarnóti lakosnak a közösségi kertjükben és a gyümölcsfeldolgozó manufaktúrájukban, amit a Norvég és Svájci Civil Alap és nemzetközi alapítványok támogatásával építettek fel. A 7 állandó foglalkoztatotton felül hozzávetőleg 15 helyi asszonynak biztosítanak jövedelemszerzési lehetőséget, és a helyiek „önkéntesként”, adományokért cserébe is vállalhatnak munkát az alapítványnál.

A helyi fejlesztés kulcsszereplőivel készített félig strukturált interjúkat (összesen 6 interjú) egy egyhetes terepi látogatással és dokumentumelemzéssel (az alapítvány Facebook oldala, a helyi asszonyok által létrehozott Facebook csoport, az alapítvány pénzügyi jelentései és projekteket leíró dokumentumai, illetve az alapítvány munkatársainak blogbejegyzései) egészítettem ki. A terepi látogatás célja az volt, hogy informális keretek között tudjak beszélgetni az Egyenlőség Alapítvány helyi munkavállalóival és egyéb „kedvezményezettjeivel”, illetve azokkal a helyiekkel, akik nem tartoznak közvetlenül az Egyenlőség Alapítvány szűkebb kedvezményezetti körébe.

A terepi látogatás alatt volt alkalmam beszélgetni és többször meglátogatni az alapítvány helyi oláhcigány kulcsszereplőjét és családját, beszélgettem a helyi Roma Önkormányzat oláhcigány vezetőjével, ${ }^{4}$ több idősebb helyi nem roma asszonnyal, akik nyugdíj melletti keresetkiegészítésként hímeznek az alapítvány megbízásából. Azzal az idős asszonnyal is volt lehetőségem beszélgetni, akiről a településen azt mondták, hogy uzsorakölcsönöket ad a helyieknek. Beszélgettem egy korombeli anyával és az ő édesanyjával. Mindketten mélyszegénységben élnek gyermekeikkel a település „cigánysorán”, az alapítvány által szervezett babamama klub rendszeres látogatói, illetve hímeznek alkalmi munkában az alapítvány részére. Egy romungro roma asszonnyal is volt alkalmam beszélgetni, aki az alapítvány munkatársa. A település polgármestere, aki mezőgazdasági vállalkozó 
is egyben, nem volt elérhető a terepi bejárás idején. A palyazat.gov.hu adatbázisa alapján a település önkormányzata 2007 és 2019 között nem tudott uniós forrást vonzani a település fejlesztésére. A polgármester és az alapítvány közötti viszony nem mentes a súrlódásoktól.

A helyi fejlesztés folyamatát többszörösen hierarchikus viszonyrendszerben értelmeztem, amely kiterjedt a fejlesztő szervezet és az állam, a fejlesztő szervezet és a fejlesztést finanszírozó NGO-k, valamint a fejlesztő szervezet és a fejlesztés „kedvezményezettjei” viszonyrendszerének vizsgálatára. A helyi fejlesztés értelmezését az autonómia különböző megközelítései segítették.

\section{A helyi fejlesztés kihívásai}

\section{Az aprófalvakban történő gettósodás intézményi keretei}

Tarnót népessége 301 fö (KSH 2011), 1980 óta aprófalunak számít. A település mérete miatt is marginalizálódott Magyarország településhálózatán belül. Ennek eredményeként lakosságcsere ment végbe a településen. Az aprófalvak jelentős részében történő lakosságcsere a romák rasszizálódásához és társadalmi-területi marginalizálódásához köthető.

Az államszocializmus regionális fejlesztési szakpolitikái a 3000 főnél kevesebb lakost számláló településeket, azaz a teljes aprófalvas állományt, a „feudalizmus örökségének”, „életképtelennek” minősítették (Bajmócy, Józsa, Pócsi 2007; G. Fekete 2005, 2015; OTK 1971). Ennek eredményeként a 3000 fönél kisebb településeken élőknek infrastrukturális ellátatlansággal, rossz életkörülményekkel, a munkalehetőségek hiányával, gyenge tömegközlekedési kapcsolatokkal kellett szembenézniük. A területfejlesztési szakpolitikákban stigmatizált településeken lakosságcsere zajlott le. A jobb társadalmi-gazdasági helyzetű lakosok tömegével hagyták el ezeket a településeket (Bajmócy, Józsa, Pócsi 2007; Kulcsár 1976) már a szocializmus idején, míg helyükre az alacsonyabb társadalmi-gazdasági státuszú lakosok „szorultak”, akik között a romák felülreprezentáltak (Lennert et al. 2014). A szocialista állam, nem feltétlenül szándékoltan, de felerősítette ezt a folyamatot. Az MSZMP 1961-es határozata (Kocsis, Kovács 1999) annak ellenére, hogy az a „cigánytelepek” felszámolására irányult, hozzájárult ahhoz, hogy a romák a strukturálisan hátrányos helyzetű régiókban koncentrálódjanak. A határozat értelmében a romák az állam által épített, csökkentett minőségű ún. „Cs”- házakba kényszerültek, vagy hitelt vehettek fel házvásárlásra (Csalog 1984). A hitel azonban csupán arra volt elegendö, hogy földrajzilag periférikus, a középosztály számára nem vonzó, ezért szelektív elvándorlásban érintett aprófalvakban vásároljanak ingatlanokat (Lennert et al. 2014). Számos észak- (Cserehát) és délnyugat-magyarországi (Ormánság) település ekkor ért el roma többséget (Kovács 2005). ${ }^{5}$ 
A rendszerváltozás után egyes régiók településein a népességcsere (szukcessziója) újra kitermelte az egyszer már felszámolt szegregátumokat (Lennert et al. 2014). 2004-re a roma családok 72 százaléka újra szegregátumokban élt (Kemény, Janky 2004). A romák társadalmi-térbeli marginalizációját az is jól mutatja, hogy a roma lakosság felülreprezentált az alacsony életszínvonallal, szegénységgel és halmozottan hátrányos helyzettel jellemezhető vidéki településeken. A teljes roma lakosság 49,5 százaléka „szorult” deprivált terekbe (Koós 2015).

$\mathrm{Az}$ állam által is támogatott társadalmi-térbeli átrendeződés (a jobb társadalmi-gazdasági helyzetben lévők szelektív elvándorlása és a rosszabb társadalmi-gazdasági helyzetben lévők szelektív bevándorlása) már a szocializmusban elkezdődött Tarnóton. Ez folytatódott a rendszerváltozás után, például az olcsóbb lakhatás miatt a 2000-es évek elején költözött a budapesti 8. kerületből Tarnótra egy nagyobb oláhcigány család (Interjú_H2_I4; Egyenlőség Alapítvány 2016). A településen tősgyökeresenek számító romungró romákkal való kapcsolatuk konfliktusos. Az alacsony lakhatási költségek miatt több nem roma család is Tarnótra költözött Romániából.

\section{A gettósodás „megélt" dimenziói}

Az oktatás és a munka kiutat jelenthetne a marginalizált helyzetből, azonban a gettósodó falvakban élők számára más minőségben érhető el a munkaerőpiac vagy az oktatás, mint az ezeken a falvakon kívül élő lakosság számára.

Munka. A helyi téesz bezárásával Tarnót gazdasága összeomlott 1989 után. A rendszerváltozást követő foglakoztatási válság (tartós munkanélküliség, foglalkoztatás a szürke- és feketegazdaság keretein belül) után a település fő foglalkoztatója a közmunkaprogram térhódításának köszönhetően a helyi önkormányzat lett, a 301 föt számláló településen (KSH 2011) 70 föt foglalkoztattak. A közmunka ugyan állandó jövedelmet jelent a családoknak, viszont a szegénységből való kitörésre nem elegendő, és a polgármestertől való függést, a patrónus-kliens viszonyt is erősíti. Az egyéb jövedelemszerzési lehetőségek sokszor a szürkegazdaságban érhetőek csak el. Vannak olyan családok, akik az erdőben és mezőkön található termények, virágok (pl. bodzavirág, galagonya, csipkebogyó) gyüjtésével egészítik ki a jövedelmüket. (A csipkebogyó-átvételt $80 \mathrm{Ft} / \mathrm{kg}$-os áron hirdette egy helyi vállalkozó a faluban). Mezőgazdasági idénymunka is elérhető, azonban a vállalkozók sokszor nem jelentik be az alkalmi munkavállalókat. A nem bejelentett jövedelem következtében elesnek a szürke- és feketegazdaságba kényszerült munkavállalók a társadalom- és nyugdíjbiztosítástól. Rozi, az Egyenlőség Alapítvány romungro roma munkatársa korábban maga is mezőgazdasági idénymunkából keresett pénzzel egészítette ki a családi költségvetést. Számára kitörési lehetőséget biztosított az alapítványnál elérhető állandó, bejelentett munka.

A hiányos tömegközlekedés mellett (napi két buszjárat a szomszédos településre) az egy főre jutó gépkocsik száma is alacsony, ami tovább nehezíti a munka- 
helyekre járást, és ez erősíti a helyi lakosok „bezáródását” az egyre inkább magára hagyott vidéki térbe. A szélsőséges marginalizáció folyamatai sokszor választás elé állítják a „vidéki gettók” lakóit a külföldi munkavállalás vagy a helyben maradás és a különböző mértékű illegális gyakorlatok között: „(...) én tudtam aztat, hogyha én nem megyek el távolra dolgozni, akkor nincs értelme. Tudtam azt, hogyha itt maradok, akkor lehet, hogy viszem tovább azt a bünözői életmódot." (Interjú_H2_I4)

A nők gazdasági kényszer vagy egyéb kényszerítő erő hatására vállaltak szexmunkát, akár külföldön is. Ilyen németországi munkavállalásról szereztem tudomást (Terepi jegyzet_H2). Jól ismert, hogy az 1990-es évek óta kerülnek ki nők és lányok közép- és dél-európai országokból, hogy kényszerített szexmunkásként dolgozzanak az Európai Unió gazdagabb országaiban (Kóczé 2011). Fontos megértenünk, hogy miért bizonyos országok bizonyos régióiból érkező nők teszik ki a kényszerített szexmunkások többségét (Kóczé 2011). A gettósodó falvakban élő roma nők elleni erőszak komplex természetének megértéséhez a különböző társadalmi egyenlőtlenségek, hierarchiák és hatalmi relációk (társadalmi nem, etnicitás, lakóhely, geopolitikai-gazdasági és osztályhelydimenziók) dinamikus kölcsönhatásának (interszekcionalitásának) vizsgálatára van szükség.

A férfiaknál is felmerült a külföldi vendégmunka (föként Németországban és Ausztriában) mint a nyomorból való kitörés „tisztességes” lehetősége. „Tisztességes", összehasonlítva a lopással vagy a betöréssel (Interjú_H2_I4). A közmunka mint a helyben elérheto „tisztességes munka” nem nyújt elegendő jövedelmet a család fenntartásához: „ötvenezerből nem tudom eltartani őket” (Interjú_H2_I4). A külföldi munkavállalás egyik fő motivációja a gyermekek materiális szükségleteinek „tisztességes” úton történő kielégítése és példamutatás a „tisztességes” életre (Interjú_H2_I4), amelynek során azonban sérül a szülő-gyermek kapcsolat: „az első 4 évben a fiam nem nekem mondta, hogy apu, hanem a nagybátyámnak. [A feleségem] édes bátyjának mondta, hogy apu. Nem bántott engemet, nem zavart tudod egyáltalán, de belegondoltam sokszor, hogy volt-e ennek értelme. (...) nem bántott, mert áldozatot kell azért hozni, hogy jobb lehessen, tudod?" (Interjú_H2_I4).

Oktatás. Az oktatás segíthetné a szélsőségesen marginalizált terekből való kitörést, azonban a gettósodó településeken élő gyerekeknek nem sok esélye van nem szegregált iskolába vagy óvodába járni. Az oktatásban jelenlévő etnikai alapú szegregáció miatt képtelen a magyar oktatási rendszer a társadalmi egyenlőtlenségek mérséklésére. Az oktatási szegregációt részben az is magyarázza, hogy a nem roma szülők olyan iskolákba íratják be a gyermekeiket, ahol a roma tanulók aránya alacsony. Másrészről az egyházi iskolák szabadon dönthetnek arról, hogy melyik gyermeket veszik fel, ez is erősítheti az etnikai alapú szegregációt. A Tarnót melletti településen működő egyházi iskola csupán kevés hátrányos helyzetű roma gyermek számára biztosít oktatást, így a helyi állami iskolában koncentrálódnak a hátrányos helyzetű roma gyermekek (Egyenlőség Alapítvány 2016; H2_D9). Anikó, egy Tarnóton élő oláhcigány asszony nem szeretné a gyermekeit a 
helyi állami iskolába beíratni, hiszen „az szinte teli van cigány gyermekekkel” (Terepi jegyzet_H2). Az egyházi iskolák az állami iskolákkal megegyező mértékű normatív alapú állami támogatást kapnak személyi kiadások esetén, viszont a működési kiadásokra az állami iskolák az egyházi iskoláknak járó normatív támogatások csupán 36\%-át kapták 2017-ben. Ezen felül az állami iskolákkal ellentétben az egyház is mögöttük áll a vagyonával (Ercse 2018; Kövér 2015). ${ }^{6}$ Azzal, hogy az egyéni autonómia fejlesztéséhez szükséges intézményrendszer elérhetetlenné válik a gettósodó vidéki terekbe „szorult” lakosság számára, az állam hozzájárul a szélsőséges társadalmi-térbeli marginalizáció újratermelődéséhez.

Az oktatási rendszerhez és a munkerőpiachoz való hozzáférés egyenlőtlen Magyarországon. A szélsőségesen marginalizált terekben élő lakosság számára nem jelent kiutat a szegénységből és többszörösen marginalizált helyzetből a szegregált oktatásban vagy a patrónus-kliens viszonnyal jellemezhető közmunkában és alkalmi munkákban való részvétel. A külföldi munkavállalás a nyomorból való kitörés egyéni stratégiájaként azonban sokszor új függőségi viszonyokba ágyazza a helyi cselekvőket, így nem jelent tényleges kitörési lehetőséget a marginalizált helyzetből.

\section{A helyi fejlesztés lehetőségei és korlátai Tarnóton}

A gettósodó terekben élők alulról szerveződésének lehetőségeit az egyéni, kollektív és szervezeti autonómia fogalma magyarázza. A szervezeti autonómia és az intézményi keretek mutatják, hogy milyen lehetőségei vannak a civil kezdeményezéseknek arra, hogy a szélsőséges társadalmi-térbeli marginalizációt helyi szintről mérsékeljék. A kollektív és egyéni autonómiát befolyásolja, hogy az adott helyi fejlesztési kezdeményezés döntéshozatalában mennyire ismerik el a helyiek képességeit, illetve hogy mennyire reflektálnak az etnikai és nemi alapú strukturális elnyomásra.

\section{A helyi fejlesztés intézményi keretei}

A helyi fejlesztés fóbb narratívái. Egy demokratikus és társadalmilag igazságos állam olyan társadalmi, politikai és jogi intézményeket fejleszt, amelyek segítik az állampolgárok autonómiáját (Mackenzie 2014a, b). Magyarországon azonban az állampolgárok autonómiáját segítő intézményrendszer hiányzik. A civil szféra és az állam viszonyát inkább az állami kontroll, mintsem a partnerség határozza meg (Mihály 2019a, b). Az államszocializmus összeomlását követő demokratikus fordulat (lásd Kövér 2015) után az 1990-es évek második fele óta polarizálódás zajlik a magyar nonprofit szektorban, amelynek eredményeképpen a politikailag kevésbé autonóm nagy nonprofit szervezetek az erőforrások jelentős részével rendelkeznek, míg az alulról szerveződ”, „klasszikus értelemben vett” civil szervezetek erőforrásokhoz való hozzáférése egyre inkább marginális (Bocz 2009). A nonprofit 
szervezetek polarizálódásának folyamatába illeszkedik, hogy a kisebb helyi civil szervezetek sorvadásnak indultak a 2000-es évek elején a jóléti szolgáltatások finanszírozásának centralizációja ${ }^{7}$ következtében (Kövér 2015). A helyi civil szervezetek finanszírozásának kiszámíthatatlanná válása mellett az egyházhoz kötödő szervezetek finanszírozása megerősödött. ${ }^{8}$ Az egyenlőtlen finanszírozás eredményeképpen a kisebb humanitárius szolgáltatásokat nyújtó civil szervezetek tönkrementek vagy összeolvadtak a helyi egyházi szervezetekkel (Kövér 2015).

A közfoglalkoztatási program 2010-et követő térnyerésével a helyi szereplők közül elsősorban az önkormányzatokra hárul a munkaerőpiacról tartósan kiszorult helyiek foglalkoztása. A közfoglalkoztatási program térnyerését a szociálpolitikában bekövetkezett radikális fordulat előzte meg. Az ideológiai fordulatot a 2000-es évek elején bekövetkező társadalmi feszültségek eredményezték. Az állam az állampolgárok munkaerőpiaci aktiválásában látta új szerepét, véget vetve ezzel a ,jóléti függőségnek”, amit az 1989-et követő politikai átmenet szociálpolitikájának tekintettek (Vidra 2018). A 2000-es évek elejétől Magyarország mind jobb-, mind baloldali kormányai a jóléti (,welfare”) állam színlelése helyett a „,munkaalapúnak”, illetve „munkaközpontúnak” nevezett - valójában inkább munkakényszeren (,workfare") alapuló - modellt építik (Csoba 2010; Éber 2018; Vidra 2018), a „képessé tételt” munkára való szocializálásként értelmezik. Hangsúlyozzák az egyén felelősségét a munkanélküliség felszámolásában („responsibilization”), figyelmen kívül hagyják a munkanélküliség strukturális okait ${ }^{9}$ és támogatják az államot a jóléti szolgáltatások leépítésében (van Baar 2012; Keller et al. 2016). A társadalmilag és térben is marginalizált romák felülreprezentáltak a közfoglalkoztatási programokban (van Baar 2012). A közfoglalkoztatási programokhoz kapcsolódóan gyakran jelenik meg a "segély helyett közmunka” narratíva. Ez a narratíva azért vitatható, mert azáltal, hogy a szegényeket „érdemes” és „érdemtelen” szegényekre osztja, rasszizálja a szegénységet. „Érdemtelen” szegények ebben a narratívában azok, akik „önhibájukból élnek szegénységben” (,a romák, akik nem szeretnek dolgozni”), és az „érdemes” szegények azok, akiknek „jár segítség”, hiszen „önhibájukon kívül” élnek szegénységben (,,a nemromák, akik a gazdasági szerkezetváltás vagy a pénzügyi válság áldozataivá váltak") (Vincze 2014b). Az Egyenlőség Alapítvány narratívája nem illik a közfoglalkoztatási programok mögött álló, az egyén felelősségét hangsúlyozó narratívákba. Ezzel összhangban nem is tudott az alapítvány a közfoglalkoztatás keretein belül foglalkoztatni. Az alapítvány perspektívájából a faluban működő közfoglalkoztatási program elszívta az alapítvány potenciális munkavállalóit (lásd Mihály 2019a). Míg az alapítvány (állami támogatások hiányában) kevéssel tudott több pénzt ajánlani, mint a közfoglalkoztatott bér, addig a közmunkához képest magasabb volt a munkavégzés természetével kapcsolatos elvárás (Blogbejegyzés 2016; H2_D5). A munkavégzés szempontjából a közfoglalkoztatási programban gyakran jelenlévő ellenőrzés-központúsággal szemben az alapítványnál a munkavállalók 
belső motivációját kívánják erősíteni (Blogbejegyzés 2017; H2_D26). Terepi látogatásom alkalmával én is azt láttam, hogy az alapítványnál a munkafeladatok megszervezése kevésbé a munkáltatói kontrollra, mint a munkavállalók belső motivációjára épít (Terepi jegyzet_H2). Mint több más közfoglalkoztatási programban (Váradi 2016), Tarnóton is hiányzik a munkavállalói kompetenciák fejlesztését célzó szemlélet és az ahhoz szükséges szakmai (pl. szociális munkás, mint közfoglalkoztatás-szervező) tudás. A faluban azt beszélték, hogy a polgármesteri hivatal által szervezett közmunkában elég csak „aláirni bemenni” (Terepi jegyzet_H2).

A civil szektorban a képessé tétel neoliberális és részvételi diskurzusokon ${ }^{10}$ keresztül definiálódik (Ivasiuc 2018). Több roma civil szervezet is versenyez a fejlesztési forrásokért, aktivista elköteleződésüket azonban gyakran eltérítik a neoliberális szakpolitikák, diskurzusok vagy a finanszírozó szervezetek által rájuk erőltetett témák (Acton, Rostas, Ryder 2014). Kóczé szerint Kelet-Közép-Európában bizonyos NGO programok olyan neoliberális állam logikájára építenek, amely a szociális szolgáltatásokat privatizálja vagy filantropizálja. Ezekben az NGO programokban a roma nők „,képessé tétele” gyakran a neoliberális állam logikájába illeszkedik, azaz a ,jóléti szolgáltatásoktól való függés" megszüntetése kódolódik „képessé tételként” (Kóczé 2016b). A roma közösség és az egyének kizárólagos felelősségének hangsúlyozása azonban nem lehet társadalmilag fenntartható stratégia, hiszen az figyelmen kívül hagyja a nemi és rasszizált strukturális elnyomást. Ahelyett, hogy az önmagáért felelős roma anya képét alkotjuk meg, fontos lenne az állam szerepét is meghatározni (Kóczé 2016b). Az Egyenlőség Alapítvány narratívája nem illeszkedik a romák társadalmi integrációját érintő domináns neoliberális narratívákba, amelyek a romákat teszik felelőssé a társadalmi kirekesztés magyarázatában, és figyelmen kívül hagyják a többségi társadalom és az intézményi közeg felelősségét a romák elnyomásában.

A civil szektor intézményesülése során azok a civil kezdeményezések, amelyek nem illeszkednek a neoliberális ( $\mathrm{pl}$. „segély helyett közmunka”) vagy a többségi társadalom-központú diskurzusokba, egyre inkább elzáródnak a pénzügyi erőforrásoktól és azoktól platformoktól, amelyeken keresztül a különböző állami intézményekkel, minisztériumokkal párbeszédet alakíthatnának ki (hasonló folyamatokat dokumentált Spanyolországban Caro Maya, Werner Boada 2019). Az Egyenlőség Alapítvány a képessé tételt a részvételiség erősítésén keresztül értelmezi, és a marginalitást újratermelő mechanizmusai miatt kritizálja a helyi fejlesztés intézményi kereteit. Ennek következtében egyre kevésbé fér uniós vagy állami forrásokhoz, illetve szűkül a lehetősége, hogy párbeszédet folytasson a szakpolitikai döntéshozókkal.

Pénzügyi erőforrásokhoz való hozzáférés. 2014 óta az állami beavatkozások egyre kisebb teret biztosítanak a politikailag autonóm (sok esetben rendszerkritikus) civil kezdeményezések számára. A Norvég Civil Alap kapcsán (Kelemen-Varga et al. 2017) a Norvégia és Magyarország között kialakult diplomáciai konfliktus 
arra mutat rá, hogy a magyar állam egyre inkább igyekszik kiterjeszteni az ellenőrzést a civilek számára elérhető erőforrások felett. Az Egyenlőség Alapítvány számára fontos bevételi forrást jelentettek a Norvég és Svájci Civil Alapnál megpályázható források. 2013 és 2016 között az Egyenlőség Alapítvány $43000000 \mathrm{Ft}$ pályázati támogatáshoz jutott hozzá (Egyenlőség Alapítvány, pénzügyi kimutatások; H2_D27). A pályázatokból származó összegeket a tarnóti integrációs modell továbbfejlesztésére költötték, azaz a digitális analfabetizmus felszámolására, háztartási és gyermeknevelési ismeretek átadására, közösségfejlesztésre, a közösségi ház bevezetésére a falu életébe és a kiskert programra, amellyel a helyiek önfenntartási készségeit igyekeznek fejleszteni (Egyenlőség Alapítvány; pénzügyi kimutatások; H2_D27). A kieső forrásokat (Norvég és Svájci Civil Alap) az alapítvány vállalatoktól származó megrendelésekből, a vállalatokhoz vagy más nemzetközi alapítványokhoz kötődő pályázati nyereményekből és kisebb magánadományokból igyekszik fedezni.

Az alulról szerveződő kisebb civil szervezetek közpénzekhez való hozzáférése országszerte gyengül. Ez a folyamat az Egyenlőség Alapítványnál is azonosítható. Míg az alapítvány 2012 és 2015 között összesen 55000000 Ft uniós pályázati forrást tudott vonzani Tarnót településére a TÁMOP keretein belül (mindkét esetben tanoda megnyitására és fenntartására), ${ }^{11} 2015$ után nem volt sikeres EU-s pályázatuk. A 2016-ban kiírt EFOP-3.3.1-15 tanodapályázaton annak ellenére nem nyertek, hogy szakmailag elismert, tapasztalt szervezetnek számítottak. A TanodaPlatform ${ }^{12}$ tanodákat tömörítő érdekérvényesítő szervezet kutatása szerint a legtöbb civilekhez kötődő tanoda nem nyert az EFOP 2016-os pályázatán. A bizonytalan finanszírozási környezet következtében több tanoda is tönkrement. Más tanodák túlélési stratégiája az volt, hogy alternatív, a központi költségvetésen kívüli finanszírozási forrásokat kerestek, miközben továbbra is közfeladatokat láttak el. A tarnóti tanoda stratégiája ez utóbbi volt:

„Azzal, hogy nem nyertünk, kaptunk egy új, nem könnyü, de szép és kreativitást igénylö feladatot, ugyanis meg kell teremteni a müködésünk feltételeit. És ez jó. Azért jó, mert régóta látszik, hogy amennyiben nem vagyunk képesek több lábon állni - leginkább sajátokon -, akkor megette a fene az egészet. És itt hibáztunk óriásit, mert hagytuk magunkat megvezetni. Amikor 2015 végén beadtuk a pályázatunkat, azt gondoltuk, hogy legkésőbb márciusban megtudjuk, hogy kapunk-e támogatást vagy sem. Aztán elhittük a harminc napos haladékot. Aztán teltek a napok, hetek, hónapok és 2016.09.21. lett. (...) nem kellett volna abban hinni, hogy holnap lesz lista [a tanodapályázat nyerteseiröl] és akár még nyerhetünk is." (az Egyenlőség Alapitványhoz tartozó tanoda program vezetőjének blogbejegyzése; 2016, H2_D23).

A szakpolitikákkal vagy az intézményrendszerrel szembeni kritikát megfogalmazó civilek elnémítása a jóléti szolgáltatásokból való kiszorításukon túl (a központi költségvetésből érkező források megvonása) a „külföldről finanszírozott szervezetként" történő megbélyegzésükkel is elérhető. A külföldről finanszírozott 
szervezetek átláthatóságáról szóló törvény (elfogadva 2017. június 13-án) értelmében, regisztrálniuk kell, illetve a weboldalukon fel kell tüntetniük azoknak a civil szervezeteknek ,a külföldről finanszírozott szervezet” megnevezést, melyek évente 7 millió Ft-nál nagyobb összegü támogatást kapnak (G. Fekete et al. 2017, 2018). Az Egyenlőség Alapítvány is e törvény hatálya alá esik. ${ }^{13}$

Párbeszéd szakpolitikai döntéshozókkal. Az oktatási szegregációban az intézményrendszer felelősségét firtató Egyenlőség Alapítvány vezetőjét sem hívják már meg szakértői előadást tartani minisztériumi rendezvényeken (Interjú_H2_I6). Ezen felül az alapítvány vezetője tagja volt a 2013-ban Balog Zoltán, korábbi emberi erőforrások minisztere által létrehozott antiszegregációs kerekasztalnak. Mivel az alapítvány vezetője a romák marginalizációját újratermelő intézményi mechanizmusokra világított rá, és ezzel a nézetével egyre inkább kisebbségben maradt, úgy döntött, önként lép ki az antiszegregációs kerekasztalból:

„Én, aki mindig azt hangoztatom, hogy mennyire fontosnak tartom a munkánk beépitését az állami rendszerbe, ezen a vonalon feladom. Többször eljutottam már erre a pontra, fóleg, mert úgy éreztem, annyira nem egy nyelven beszélünk, annyira másképp látjuk, de mindig vártam, reméltem, hogy változik valami, és legalább mérsékelni, fékezni tudok dolgokat. (...) Az utóbbi időben már nagyon rosszul éreztem magam a pozitívumokat hangsúlyozó megbeszéléseken, miközben én a terepen pont az ellenkezőjét tapasztalom." (az alapitvány vezetöjének Facebook bejegyzése 2016).

A civil szektor működését tekintve a rendszerkritikusabb hangok „elnémítása” a pénzügyi erőforrások korlátozásával és a döntéshozatali mechanizmusokból való kiszorítással - inkább felerősíti, mintsem hogy ellene hatna a nonprofit szektorban jelen lévő patriarchális és rasszizáló diskurzusoknak (Spanyolországban lásd: Caro Maya, Werner Boada 2019).

\section{Az Egyenlöség Alapitvány és a tarnótiak: képessététel etnikai és gender szempontokból}

A tarnóti roma nők többszörösen marginalizált helyzetben vannak. Az interszekcionalitás elmélete segíthet abban, hogy megértsük azoknak a roma nőknek a helyzetét, akik az előrehaladott periferizálódás (gettósodás) körülményei között élnek. A nemi és etnicizált kirekesztés egybeesését (interszekcionalitását) „dupla kirekesztésnek", azaz a roma (és nem roma) patriarchális társadalom illetve a nem roma politikai és gazdasági rezsim kettős dominanciájának nevezik az emberi jogi aktivisták. A feminista interszekcionalitás-elméletek - harmadik új kategóriaként - az osztályhelyzetet is belefoglalják elemzésükbe. Ezáltal a „rasszosztályhelyzet-nem" megközelítés egyre inkább hangsúlyos a nemi egyenlőség diskurzusaiban (Kóczé 2011, 54.). A „roma nők” kategóriája azonban nem homogén. Azoknál a roma nőknél, akik alacsony iskolai végzettséggel rendelkeznek, fiatal korukban házasodnak, több mint egy gyermekük születik, munkanélküliek 
és vidéki területeken élnek, magasabb a szegénység és szociális kirekesztettség kockázata, mint azoknál a roma nőknél, akiknek magasabb iskolai végzettsége, munkahelye van és városban élnek (Kóczé 2011). „Ennek következtében értheto”, hogy az abszolút szegénység legmagasabb szintjét elszenvedő roma nőknek magasabb a saját közösségeikben a nemükből adódó sebezhetősége (gender-related vulnerability)" (Kóczé 2011, 74.).

Az Egyenlőség Alapítvány azon szervezetek között van, amelyek elismerik a roma nők rasszizált és nemi eredetű (gendered) strukturális elnyomását. A szervezet tematizálja az állam felelősségét, és érintettjei, köztük a mélyszegénységben élő roma nők képességszemléletű fejlesztésére törekszik. Anélkül, hogy roma feminista szervezetként definiálná magát, az alapítvány tudatosan fókuszál a tarnóti nőkre mint a helyi fejlesztés partnereire. Az alapítvány célját a nők társadalmi reprodukcióban játszott szerepe is befolyásolta.

„(...) a gyerekek érdekében az anyukák könnyebben partnerré tehetők, másrészt, mert a krízisek kezelését a családon belül nekik kell végezni, nekik kell enni adni a családnak, biztositani az életük mindennapi szervezési részét. Másrészt az egymással való kapcsolattartásban is erősebbek, és kompromisszumkészebbek, érzelmileg jobban befolyásolhatók, mint a férfiak." (Egyenlöség Alapitvány 2016; H2_D9).14

Az előzetesen kitűzött stratégiai prioritáshoz kapcsolódóan (a nők képessé tétele) sikerült az alapítványnak forrást szereznie olyan közösségfejlesztési projektre, amelynek középpontjában a tarnóti nők állnak, kortól, státusztól és etnicitástól függetlenül. A Norvég Civil Alap által támogatott (2014-2017) célzott közösségfejlesztési projekt keretein belül az alapítvány 30 nőt, fiatal, idős, „gyüttment”, „tősgyökeres”, romungro, oláhcigány és nem roma helyi lakost választott ki a településen. A kétéves közösségfejlesztést egy évig tartó helyzetfeltárás és hét éves terepi jelenlét előzte meg. A közösségfejlesztés egy problématérkép megalkotásával indult, amely a helyi asszonyok kollektív bölcsességére építve olyan területeket azonosított, amelyek a pozitív változásokat leginkább akadályozzák a faluban. A 30 különböző társadalmi hátterű tarnóti nővel közösen három közösségfejlesztési modult dolgoztak ki az alapítvány munkatársai. A modulok egymásra épülnek és - ahogyan azt az alapítvány munkatársa fogalmazza - a „könnyebbtől” haladnak a „leginkább kihívást jelento"” felé: (1) háztartási ismeretek, (2) tudatos családtervezés és gyermeknevelés és (3) képességfejlesztés, tudásátadás és segítő együttműködés a családon belüli erőszak területén (Egyenlőség Alapítvány 2016, 33; H2_D9).

Míg a háztartási ismeretek modul leginkább a különböző etnikai és társadalmi-gazdasági hátterű nők közösségét (kollektív autonómiáját) törekedett erősíteni, addig a tudatos családtervezés és a családon belüli erőszak modul az érintettek egyéni autonómiáját igyekezett fejleszteni (Mihály 2019a). A tudatos gyermeknevelés és családon belüli erőszak modul hozott fel traumákat, amelyek feldolgozását pszichológus segítette (Egyenlőség Alapítvány 2016; H2_D9). Mivel 
nem volt lehetőségem a közösségfejlesztési projektet végigkövetni, ezért nem vállalkoznék annak hatásainak az értékelésére, csupán néhány, a programhoz kapcsolódó reflexiómat osztanám meg.

A legnagyobb kihívást a családon belüli erőszak témája jelentette. A programban résztvevő nők közül többek számára nehéz volt erről a témáról beszélni (Egyenlőség Alapítvány 2016, 75-76.; H2_D9). Ennek lehetséges oka az is lehetett, hogy az alapítvány nem roma munkatársai vezették a közösségfejlesztési alkalmakat, valószínűleg olyan közeget teremtve, amelyben a roma nőknek választaniuk kellett roma vagy női identitásuk védelme között. Patricia Caro Maya és Sarah Werner Boada abban látja a nem romák részvételének előnyét a roma nők egyenjogúságáért folytatott harcban, hogy a domináns csoportok (nem roma nők és nem roma férfiak) lebonthatják azokat a struktúrákat, amelyek többlethatalommal ruházzák fel őket. Így a férfi-nő, roma-nem roma közötti falak leépítése érdekében érdemes lehet az alapítvány nem roma munkatársainak is reflektálniuk „,fehér privilégiumaikra” (,white privilege”) és a társadalmi nemükből adódó kiváltságaikra. A nők elleni erőszak nem csökkenthető anélkül, hogy ne vennénk figyelembe a kisebbségi csoportokhoz tartozó nők elleni strukturális elnyomást, amely felerősíti a párkapcsolati erőszakot is (Caro Maya, Werner Boada 2019).

Az Egyenlőség Alapítvány, szemben sok más romákat célzó helyi fejlesztési kezdeményezéssel, igyekszik túlmutatni a filantropikus segítségnyújtáson (ami az érintetteket a „segíto”"-,segített” szerepekbe betonozza), narratíváiban a részvételiséget hangsúlyozza, és a gyakorlatban igyekszik helyzetbe hozni a roma nőket. A roma nők egyenjogúságáért folytatott harcban azonban fontos lenne, hogy az alapítvány nem roma női és férfi érintettjei tudatosan figyeljenek azokra a struktúrákra, amelyek többlethatalommal ruházzák fel őket.

\section{Képessé tétel a döntéshozatal tükrében}

A civil szervezetek mérsékelhetik helyi szinten a szélsőséges társadalmi-térbeli marginalizációt, azonban ezeknek a kezdeményezéseknek kritikusan figyelniük kell a centrum-periféria viszonyokból adódó hatalmi különbségekre (Kühn 2014). Mészáros szerint kétséges társadalmi tőkéről vagy egymás közötti bizalomról beszélni olyan helyzetben, amelyben a „döntéshozók egyértelműen nem bíznak meg a helyiek kompetenciájában" (Mészáros 2013, 93.). Tarnót is a függőségek viszonyrendszerébe ágyazódik bele, többszörösen periférikus helyzetben van: a globális gazdaság félperifériáján lévő Magyarország egy periferizált településén élő romákat marginalizálja a helyi elit. Az Egyenlőség Alapítvány ebben a kontextusban tüzte ki célul a helyiek részvételi kompetenciáinak fejlesztését.

A helyiek önszerveződésre való képességének erősítése érdekében az Egyenlőség Alapítvány tudatosan vonja be a tarnótiakat a helyi fejlesztéssel kapcsolatos döntéshozatalba. Az alapítvány célja, hogy lépésről lépésre fejlessze a tarnótiak ezirányú képességét. A részvételiség fejlesztése kihívásokkal teli egy olyan közeg- 
ben, ahol a helyiek arra szocializálódtak, hogy őket nem kérdezik döntéshozatali helyzetekben. A tarnóti romák alárendelt viszonyokban való szocializálódását az is jól mutatja, hogy bár az alapítvány a hierarchikus müködés leépítésére törekszik, Rozi, az alapítvány romungro roma munkatársa mégis főnöknek hívja az alapítvány alapítóját egy kávé melletti beszélgetésünkben (Terepi jegyzet_H2). Szemben a projektalapú finanszírozás logikájával, a helyiek részvételi kapacitásának fejlesztését hosszú távon, minimum húszéves projektként képzeli el az alapítvány vezetője:

„Az alapitványunknak ez a legfontosabb célja. Hogy egy olyan társadalmi csoportot, akit sem a tanulás, sem a munka világa nem érintett meg generációk óta, képessé tegyük önmaguk megszervezésére. Az életük, közösségük képviseletére, a gondok megoldására, az egymással való kommunikálásra, a tervezésre, az önértékelésre, a lehetőségek kihasználására." (Blogbejegyzés 2016; H2_D5)

A helyiek döntéshozatalba való bevonását a „semmit róluk nélkülük” (Terepi jegyzet_H2) elv alapján igyekszik megvalósítani az alapítvány. A döntéshozatalba történő bevonás fó módja a munkahelyi értekezlet, amely 2013-ban vált gyakorlattá az alapítványnál. Az alapítvány minden tarnóti munkatársa (kivéve azokat, akik „önkéntes” pozícióban dolgoznak) részt vehet a munkahelyi értekezleten. Ezek abban különböznek egy átlagos munkahelyi értekezlettől, hogy nem kizárólag munkahelyi ügyeket vitatnak meg a résztvevők, a munkahelyi értekezletekkel az is a cél, hogy azok fejlesszék a tarnótiak készségét a döntéshozatalban való részvételre. Minden munkavállaló jegyzetet készít arról, hogy mi történt vele az előző héten (Terepi jegyzet_H2). Az alapítvány alapítója a következőképpen írja le a munkahelyi értekezletet:

„Ma volt a munkaértekezletünk. Minden pénteken délután leülünk és átbeszéljük a hetet. Már megy ez is, gördülékenyen, szervezetten. Nézem öket. Ahogy már rutinosan elöveszik a kis keményfedelü füzetet, és elmondják, napról napra, ki mit csinált. Nagyon jó látni, mennyit fejlődtek ebben. Néha belekérdezek és megdicsérek egy-egy sikeres területet. Büszkék. Örülnek, velem együtt. Van, aki felolvassa, amit írt. Más csak belenéz, úgy meséli a napokat. És van, aki otthon minden nap lediktálja a gyereknek, és most engem kér meg, hogy olvassam fel, amit egyébként fejból is tud. Senki sem cikizi érte, megbeszéltük már korábban a többiekkel. És a szabály az szabály. A füzetet vezetni kell, annak is, akinek nem megy az írás. Mert a munkakör kötelez. Ilyenkor annyira érzem, hogy van értelme. Érzem, ahogy egyre erösebbek lesznek lelkileg. Ahogy a feladat, a munkakör felelössége fejleszti óket. Mindenben. Céltudatosságban, kommunikációban, együttmüködésben. Ahogy közösségként egyre jobban müködnek. Már nem arról szól a gyülés, hogy egymást piszkálják. Sőt, amin csak lehet, azon jókat nevetnek.” (Blogbejegyzés 2016; H2_D5) Ezzel az alapítvány olyan normarendszert hozott létre, ami egymás pozitív megerősítésén és kölcsönös elfogadásán alapszik. Az alapítvány tarnóti munkatársai megjegyzik egy beszélgetésünk kapcsán, hogy azért szeretnek az alapítványnál dolgozni, mert itt jó a hangulat és „senki nem nézi le” őket (Terepi jegyzet_H2). 
Ahogyan azt a tarnóti példa mutatja, még a szélsőséges marginalizáció kontextusában is van lehetőség a részvételi demokrácia fejlesztésére. A munkavállalói pozíciókhoz tartozó kötelezettségek definiálásával az alapítvány igyekszik megelőzni azt, hogy bebetonozza az érintettjeit a segítő-segített pozíciókba. Az alapítvány igyekszik elismerni az összes tarnóti érintett autonómiáját (státusz), azonban tisztában vannak azzal is, hogy az autonómia gyakorlásához szükséges kompetenciákat a társadalmi, politikai, gazdasági és oktatási hátrányok, vagy a bántalmazás, kényszerítés, erőszak, illetve a tisztelet hiányával jellemezhető tárasadalmi viszonyok negatívan befolyásolják (Mackenzie 2014a). Azáltal, hogy az alapítvány a tarnótiak részvételi kompetenciáit igyekszik fejleszteni, fejlesztési alternatívát valósít meg. Filantropikus helyett demokratikus szolidaritáson alapszik a fejlesztési stratégiájuk. Sok helyi fejlesztési projekt naív optimizmusával szemben az alapítvány reflektál a tarnótiak strukturális elnyomására (oktatás, munka, egészségügy, lakóhely) és hosszú távú célkitűzéseket fogalmaz meg, az érintettek autonómiájának lépésről lépésre történő fejlesztésével.

Az Egyenlőség Alapítványban rejlő helyi fejlesztési potenciált, az alapítvány és a tarnótiak közötti viszony mélyebb megértését egy hosszabb és rendszeresebb terepi vizsgálat segítené.

\section{Van kiút a gettósodásból? A helyi fejlesztés lehetőségei és korlátai}

A romák hosszú távú strukturális elnyomását fenntartja, hogy olyan terekbe szorította őket a társadalom, amelyeket elavultnak, funkcióját vesztettnek tekint (Bajmócy, Józsa, Pócsi 2007). A szélsőségesen marginalizált vidéki terek más életlehetőségeket kínálnak lakóiknak, megnehezítve a gettósodó kistelepüléseken élők lehetőségét a nyomorból való kitörésre, és mentesítve egyben a többségi társadalmat a mélyszegénységgel való mindennapos konfrontációtól.

Az egyéni stratégiák sokszor újratermelik a szélsőséges társdalmi-térbeli marginalizációt. A gyermekek szegregált oktatásból való kimenekítése sokszor túl nagy terhet ró a szülőkre. A patrónus-kliens viszonnyal jellemezhető közfoglalkoztatásból vagy az alulfizetett alkalmi munkákból való kitörést segítheti a külföldi munkavállalás, azonban a külföldön elérhető munkák sokszor szintén kizsákmányolóak és nem biztosítanak tényleges lehetőséget a marginalizált helyzetből való kitörésre.

Az esettanulmányomul szolgáló gettósodó településen létrejött civilalapú helyi fejlesztés megmutatta, hogy a strukturális elnyomás ellenére a szélsőségesen marginalizált csoportoknak is van cselekvő ereje. Azonban éppen a strukturális elnyomás az, ami miatt szüksége van a gettósodó falvakba záródott lakosságnak a külső segítségre. A helyi fejlesztés a hatalmi egyenlőtlenségek kontextusában értelmezhető. A hatalmi egyenlőtlenségek megjelennek a fejlesztő szervezet és az állam viszonyában. Magyarországon egyre inkább az állami kontroll és 
klientalizmus az, ami meghatározza a civilek és az állam viszonyát (Ferreira et al. 2019; Kövér 2015) és ezáltal a helyi fejlesztés lehetőségeit is. Ennek következtében a szakpolitikákkal vagy az intézményrendszerrel szembeni kritikát megfogalmazó civilek kiszorulnak a jóléti szolgáltatásokból (Európai Bizottság 2019). Azon felül, hogy egyre kevesebb közpénzhez jutnak a politikailag autonóm civil szervezetek, a külföldi alapítványoktól érkező támogatás elfogadása miatt stigmatizálódhatnak is (az Egyenlőség Alapítványnak is fel kellett tüntetnie a weboldalán a megbélyegző „külföldről finanszírozott szervezet” megnevezést).

A hatalmi egyenlőtlenségek a helyi fejlesztés döntéshozatalában leképeződő centrum-periféria viszonyokban (kistelepülés és fóváros, helyi elit és marginalizált helyiek) is megmutatkoznak, beleértve a fejlesztő szervezet és a fejlesztés „kedvezményezettjei" közti hatalmi egyenlőtlenségeket. A helyi fejlesztési projektek társadalmi fenntarthatóságának szempontjából fontos, hogy az érintettek autonómiáját növeljék olyan módon, hogy képessé tegyék őket a támogató segítségtől egyre inkább független működésre. Egy fejlesztő szervezet több módon is hozzájárulhat a helyiek autonómiájának növeléséhez. A helyiek autonómiakapacitása lépésről lépésre fejleszthető, ha a fejlesztő szervezet kritkusan kezeli a hatalmi egyenlőtlenségeket (beleértve a fejlesztő szervezet és a fejlesztés „célcsoportjai” közti hatalmi egyenlőtlenségeket is, lásd Mosse 2005), bevonja a marginalizált csoportokat is a döntéshozatalba, illetve fejleszti az érintettek részvételi demokráciához szükséges készségeit. A helyiek autonómiakapacitása azzal is fejleszthető, ha a fejlesztő szervezet reflektál a nemi alapú és rasszizált strukturális elnyomásra. A roma nők megerősítését célzó Egyenlőség Alapítvány több tagja nem roma férfi vagy nő. A patriarchális és rasszizáló struktúrák leépítése érdekében érdemes lehet az alapítvány nem roma munkatársainak is kritikusan figyelembe venniük a „fehér privilégiumaikat" vagy a társadalmi nemükből adódó kiváltságaikat. A nők elleni erőszak nem csökkenthető anélkül, hogy ne vennénk figyelembe a kisebbségi csoportokhoz tartozó nők elleni strukturális elnyomást, amely felerősíti a párkapcsolati erőszakot is (Caro Maya, Werner Boada 2019).

A gettósodó vidéki terekben történő „ellenállást” számos strukturális mechanizmus nehezíti. A civil szervezeteket érintő intézményi keretek egyre kevésbé segítik az állampolgárok autonóm szerveződését, a civil szervezetek politikai autonómiájának megőrzését. Az egyre inkább szegregálódó oktatási rendszer és a patrónus-kliens viszonyrendszert felerősítő közfoglalkoztatás és alkalmi munka tovább korlátozza az egyéni és kollektív autonómiájukban egyébként is meggyengített, vidéki „gettókba” szorított lakosságot, a képességszemléletű fejlesztést megvalósító szervezetek legfontosabb szövetségeseit. A civilellenes kormányzati intézkedések kontextusában a részvételi demokrácia elvein alapuló fejlesztést megvalósító Egyenlőség Alapítvány a túlélésért küzd. 


\section{Jegyzetek}

$1 \quad$ A „critical race theory” (kritikai faji elmélet, lásd Hooks 1982; Crenshaw 1991) képviselői szerint a rasszizálódás nemcsak egyéni, hanem strukturális szinten is megjelenik, ami a legmarkánsabban a strukturális kirekesztésben nyilvánul meg. A rasszizálódás olyan hatalmi folyamat, amelyben az erősebb rasszizálja, elnyomja és leértékeli az adott ember értékeit és tulajdonságait (a normatív fehér bőrszíntől eltérő) a fekete, barna, sárga stb. bőrszíne alapján. Az egyén aktuális pozícióját tovább bonyolítja a bőrszínnel összekapcsolódó nemi és osztályhelyzete is (Kóczé 2016a).

2 A „gettó” mellett a „cigány” megnevezés is stigmatizáló lehet. Roma vagy szegény embereket gyakran stigmatizál a társadalom „cigányként”. A '90-es években a „cigány” megnevezés, negatív konnotációja miatt kerülendő volt és a politikailag korrekt „roma” megnevezés vált általánosan elfogadottá (Kovai 2018). A többségi társadalom a „roma” megnevezést a „cigány közösség” sajátjaként értékeli, annak ellenére, hogy annak csupán a romák egyik alcsoportja - a lovári nyelvet beszélő oláhcigányok - számára van jelentése. Lovári nyelven a roma „embert”, „férfit” jelent (Kovai 2018), a Magyarországon élő roma népesség 70-80 \%-a azonban romungro roma, akik nem beszélik a lovári nyelvet. A romungrók, azaz magyar cigányok azoknak a leszármazottai, akik a középkori bevándorlás után nem folytatták útjukat Nyugat-Európába. A romungrók cigány kultúrájának és identitásának elvesztésében a Mária Terézia idején történő kényszerletelepítés is szerepet játszott (Csalog 1984).

3 A félig strukturált interjú a strukturált interjú és a mélyinterjú között található: a kutatónak vannak kérdései, de van lehetőség a kötetlen beszélgetésre is, illetve közbülső kérdések feltevésére. Az interjúfajtákról bővebben: https://www.tankonyvtar.hu/hu/tartalom/tamop412A/ 2011-0021_21_kutatastervezes/623_az_interj_fajti.html, letöltve: 2019.10. 30.

4 A Roma Nemzetiségi Önkormányzat elnöke egy középkorú oláhcigány férfi, a „Lungo Drom” Országos Cigány Érdekvédelmi és Polgári Szövetség jelöltje. A Lungo Drom elnöke Farkas Flórián, fideszes politikus, az Országos Roma Önkormányzat (ORÖ) elnöke, aki az Európai Unió társfinanszírozásával megvalósulni tervezett „Híd a munka világába” munkaerőpiaci integrációs program kapcsán korrupciógyanúba keveredett. A projekt célja az ország leghátrányosabb területein élö, föként roma származású munkavállalók megsegítése lett volna foglalkoztatási szövetkezetek létrehozásával. Az EMMI 2016 márciusában elállt a „Híd a munka világába” projekttől. (Lásd: https://www.kormany.hu/hu/emberi-eroforrasok-miniszteriuma/hirek/azemmi-elall-az-oro-hid-a-munka-vilagaba-projekttol, letöltve: 2019.10.28). A Roma Nemzetiségi Önkormányzat elnöke terepi látogatásom idején közmunkásként dolgozott a településen, de volt már korábban belföldön és külföldön is vendégmunkás, illetve fél évet ő is dolgozott az alapítványnál, felesége látogatásom idején is az alapítvány munkatársa volt.

5 A szocializmus roma politikája ugyan az asszimilációs ígéretbe illeszkedett (Kovai 2018), annak voltak a romákra nézve pozitív eredményei is, mint például a lakáshoz jutás, a diszkrimináció mérséklődése és a teljes foglalkoztatás.

6 A dologi (működési) kiadásokra az egyházi iskolák 2017-ben tanulónként 160000 forint normatívát kapnak, mely összeggel szabadon gazdálkodhatnak. Az állami iskolákban az éves dologi kiadási keret 2017-ben tanulónként 57651 forint, ami az egyházi iskoláknak járó normatív keret 36\%-a. A törvényi rendelkezés alapján 2018-ra a KLIK dologi kiadási kerete - ami alapján egyáltalán kalkulálható az egy gyermekre jutó költség - 51\%-kal csökkent, azaz csökkent az egy tanulóra jutó éves összeg is, míg az egyházi iskolák működési normatívája 200000 forintra emelkedett (Ercse 2018).

7 A kormány a 2000-es évek elején rögzítette és éves szinten allokálta a helyi önkormányzatok részére a humanitárius szolgáltatások után járó normatív hozzájárulásokat (lásd Kövér 2015).

8 Az államszocializmus alatt meggyengült történelmi egyházakat kompenzálandó, 1997-ben a Magyar Kormány és a Vatikán egy együttmüködést írt alá. 2007-ben (127. áfa tv.) törvénybe foglalták, majd 2013-ban megújították a megállapodást. A pénzügyi támogatáson felül a Magyarországon müködő történelmi egyházak jelentős pénzügyi jóvátételt kaptak a Magyar 
Kormánytól a rendszerváltozás után, és 1998-tól az SZJA 1\% -a felajánlható egyházak számára (Kövér 2015).

9 A munkanélküliség strukturális okai közé tartozik például az 1989 után következő gazdasági szerkezetváltás, ami arányaiban negatívabban érintette a vidéki perifériákat (Leibert 2013), romákat (Kertesi, Kézdi 2010) és roma nőket (Kóczé 2016b).

10 A képessé tétel részvételi diskurzusai igyekeznek a több léptékben jelenlévő hatalmi egyenlőtlenségekre, valamint a nemi és rasszizált strukturális elnyomásra reflektálni.

11 TÁMOP-5.2.5/B-10/2. Gyermekek és fiatalok társadalmi integrációját segítő programok és TÁMOP-3.1.4.C-14. Innovatív iskolák fejlesztése 2. ütem.

1237 http://tanodaplatform.hu/, letöltve: 2018.12.17

13 Magyarországon kívül Oroszországban létezik még olyan törvény, ami lehetővé teszi a civil szervezetek „külföldről finanszírozott” szervezetként való megbélyegzését (Ferreira et al. 2019).

14 Azon a közösségfejlesztési alkalmon, amin részt vettem, 15-20 helyi volt jelen (romungro roma és oláhcigány, nem roma, fiatal és idős egyaránt). A közösségfejlesztő alkalmat, az alapítvány munkatársa, egy 40 körüli nem roma férfi tartotta. A település történeti fejlődéséről volt szó, azonban annak ellenére, hogy a facilitátor igyekezett megszólítani roma résztvevőket is, a nem roma résztvevők lényegesen többet szóltak a témához.

\section{Köszönetnyilvánítás}

Ezt a kutatást nem tudtam volna elvégezni a tarnótiak és az Egyenlőség Alapítvány nyitottsága és befogadása nélkül, ezt ezúton is szeretném megköszönni nekik. Köszönettel tartozom még munkatársaimnak, Nagy Erikának és Timár Juditnak (KRTK RKI Békéscsaba), illetve a két anonim bírálómnak konstruktív kritikáikért. Az Európai Unió adófizetőinek is szeretnék köszönetet mondani, hiszen a doktori kutatásomat, amelyre a tanulmány épít, a Marie Curie ITN RegPol ${ }^{2}$ projekt (People Programme, European Union's Seventh Framework Programme FP7/2007-2013/, REA grant agreement $n^{\circ}$ 607022) keretein belül tudtam elvégezni.

\section{Irodalom}

Acton, T., Rostas, I., Ryder, A. (2014): The roma in Europe: The debate over the possibilities of empowerment to seek social justice. In: Ryder, A., Cemlyn, S., Acton, T. (eds.): Hearing the voice of gypsies, roma and travellers: Inclusive community development. Policy Press, Bristol, 177-196.

Amin, A., Cameron, A., Hudson, R. (2002): Placing the social economy. Routledge, London, New York (Contemporary political economy series)

Asara, V., Profumi, E., Kallis, G. (2013): Degrowth, democracy and autonomy. Environmental Values, 2., 217-239. https://doi.org/10.3197/096327113X13581561725239

Bajmócy P., Józsa K., Pócsi G. (2007): Szélsőséges aprófalvak. Aprófalvak a településlisták végein néhány társadalmi gazdasági mutató alapján. In: Csapó T., Kocsis Zs. (szerk.): A kistelepülések helyzete és településföldrajza Magyarországon. [III. Településföldrajzi Konferencia]. Savaria Univ. Press, Szombathely, 24-37.

hooks, b. (1982): Ain't I a woman. Black women and feminism. Pluto Press, London

Berki M. (2015): A térbeliség trialektikája. Tér és Társadalom, 2., 3-18. https://doi.org/10.17649/TET. 29.2.2658

Bhaskar, R. (1989a): Reclaiming reality: a critical introduction to contemporary philosophy. Verso, London

Bhaskar, R. (1989b): The possibility of naturalism: A philosophical critique of the contemporary human sciences (second edition). Harvester Wheatsheaf, Hemel Hempstead 
Bocz J. (2009): „Jéghegyek”. Tévhitek, avagy a magyar non-profit szektor mélyrétegei. Civil Szemle, 4., 24-50.

Caro Maya, P., Werner Boada, S. (2019): The challenges of Kalí NGOization after francoism: Rethinking activism in and beyond Spain. In: Kóczé, A., Zentai, V., Jovanovic, J., Vincze, E. (eds.): The Romani women's movement. Routledge, London, New York, 227-247.

Coraggio, J., Eynaud, P., Ferrarini, A., Filho, G. F., Gaiger, L. I., Hillenkamp, I., Kitajima, K., Laville, J.-L., Lemaitre, A., Sadik, Y., Veronese, M., Vanderley, F. (2015): The theory of social enterprise and pluralism: solidarity-type social enterprise. In: Laville, J.-L., Young, D. R., Eynaud, P. (eds.): Civil society, the third sector and social enterprise. Governance and democracy. Routledge, London, New York, NY, 234-249. (Routledge frontiers of political economy 200)

Crenshaw, K. (1991): Mapping the margins: Intersectionality, identity politics, and violence against women of color. Stanford Law Review, 6., 1241-1300.

Csalog Zs. (1984): A cigánykérdés Magyarországon 1980 előtt. Magyar Füzetek, 14-15., 93-137. http:// epa.oszk.hu/02200/02201/00013/pdf/EPA02201_Ma_gyar_Fuzetek_1984_1415_093-137.pdf (Letöltés ideje: 2019.06.10.)

Csoba J. (2010): A közfoglalkoztatás régi-új rendszere. Útközben az „Út a munkához” programban. Esély 1., 4-24.

Európai Bizottság (2019): Social enterprises and their ecosystems in Europe. Updated country report: Hungary. (Szerzők: Kiss, J., Mihály, M.) Publications Office of the European Union, Luxembourg, Elérhető: http://ec.europa.eu/social/main.jsp?advSearchKey=socenterfiches\&mode=advanceds ubmit\&catId=22 Magyar fordításban elérhető: http://unipub.lib.uni-corvinus.hu/4246 (Letöltés ideje: 2019.10.02.)

Ercse K.: Az állam által ösztönzött, egyházasszisztált szegregáció mechanizmusa. In: Fejes J. B. Szűcs N. (szerk.): Én vétkem. Helyzetkép az oktatási szegregációról. Motiváció Oktatási Egyesület: Szeged 177199.

Éber M. Á. (2018): Osztályszerkezet és állami újraelosztás blogbejegyzés. Új Egyenlőség http://ujegyenloseg.hu/osztalyszerkezet-es-allami-ujraelosztas/ (Letöltés ideje: 2019.10.02.)

Ferreira, S., Mihály, M., Nogales, R., Pongo, T. (2019): The multi-dimensional reality of social enterprise in Central and Eastern Europe. Stakeholder Brief No. 1. EMPOWER-SE COST Action $16206 \mathrm{http} / / /$ www.empowerse.eu/wp-content/uploads/2019/03/SB1-WG1-Stakeholder-brief-Lisbon.pdf (Letöltés ideje: 2019.10.02.)

Gébert J., Bajmócy Z., Málovics Gy., Pataki Gy. (2016): Eszközöktől a jóllétig. A helyi gazdaságfejlesztés körvonalai a képességszemléletben. Tér és Társadalom, 2., 23-44. https://doi.org/10.17649/TET.30.2.2752

G. Fekete, É. (2005): Small villages undergoing transformation. In: Barta, Gy., G. Fekete, É., Szörényiné Kukorelli, I., Timár, J. (eds.). Hungarian Spaces and Places: Patterns of Transition. Centre for Regional Studies, Pécs, 483-500.

G. Fekete É. (2015): Csereháti diagnózisok - átfogó térségi helyzetbemutatás. G. Fekete É. (szerk.): Társadalmi innovációk a felzárkózás szolgálatában. Dél-Cserehát - Nyitás a jövőre. Miskolc, 5-51.

G. Fekete, É., Hubai, L., Kiss, J., Mihály, M. (2017): Social enterprise in Hungary, ICSEM Working Papers, No. 47, The International Comparative Social Enterprise Models (ICSEM) Project, Liege

G. Fekete É., Hubai L., Kiss J., Mihály M. (2018): Társadalmi vállalkozások Magyarországon. In: G. Fekete É., Nagy Z., Lipták K., Kiss J. (szerk.): Szociális és szolidáris gazdaság a poszt-szocialista perifériákon. Miskolci Egyetem, Gazdaságtudományi Kar, Miskolc 117-146. http://nemzetkozi-gazdalkodas.hu/files/13250/OTKA_k\%C3\%B6nyv.pdf (Letöltés ideje: 2019.10.02.)

Ivasiuc, A. (2018): Alter-narratives: Seeing ordinary agency. In: Beck, S., Ivasiuc, A. (eds.): Roma activism: Reimagining power and knowledge. Berghahn, Oxford, New York, 129-153.

Kelemen-Varga, R., Kiss, J., Oravecz, Á., Száraz, A., Várnagy, E., Bukovics, I. (2017): 4 years, 448 projects. Evaluation of the EEA Grants NGO Programme strengthening civil society in Hungary. NCTA, Budapest

Keller, J., Kovács, K., Rácz, K., Swain, N. Váradi, M. (2016): Workfare schemes as a tool for preventing the further impoverishment of the rural poor. Eastern European Countryside 1., 5-26. https://doi.org/10.1515/eec2016-0001

Kemény I., Janky B. (2004): Települési és lakásviszonyok. Beszélo, 4., 96-111. http://beszelo.c3.hu/04/04/13kemeny.htm (Letöltés ideje: 2019.10.02.) 
Kertesi, G., Kézdi, G. (2010): Roma employment in Hungary after the post-communist transition. BWP -2010/9, ISBN 978-615-5024-28-3, Hungarian Academy of Sciences, Institute of Economics, Budapest (Budapest Working Papers on the Labour Market)

Kocsis K., Kovács Z. (1999): A cigány népesség társadalomföldrajza. In: Glatz F. (szerk.): A cigányok Magyarországon. MTA, Budapest, 163-204.

Koós B. (2015): A szegénység és depriváció a magyar településállományban az ezredfordulót követően - avagy kísérlet a települési deprivációs index létrehozására. Tér és Társadalom, 1., 53-68. https://doi.org/10.17649/TET.29.1.2681

Kovai C. (2018): A cigány-magyar különbségtétel és a rokonság. L Harmattan Könyvkiadó Kft., Budapest

Kovács T. (2005): A sellyei (-siklósi) KSH-térség rövid leírása. In: Baranyi B. (szerk.): Roma szegregációs folyamatok a csereháti és dél-baranyai kistérségekben. Gondolat Kiadó - MTA Etnikai-Nemzeti Kisebbségkutató Intézet, Budapest, 29-52. http://kisebbsegkutato.tk.mta.hu/uploads/files/ archive/394.pdf (Letöltés ideje: 2018.05.26.)

Kóczé, A. (2011): Gender, ethnicity and class: Romani women's political activism and social struggles. Central European University, Budapest

Kóczé A. (2016a): Az elismerés politikája Neményi Mária munkáin keresztül. http://beszelo.c3.hu/onlinecikk/az-elismeres-politikaja-nemenyi-maria-munkain-keresztul (Letöltés ideje: 2019.10.02.)

Kóczé, A. (2016b): Romani women and the paradoxes of neoliberalism: Race, gender and class in the era of late capitalism in East-Central Europe. In: Kováts, E. (ed.). Solidarity in struggle. Feminist perspectives on neoliberalism in East-Central Europe. Friedrich Ebert Stiftung, Budapest, 42-53.

Kövér, Á. (2015): Captured by state and church: Civil society in democratic Hungary. In: Krasztev, P., van Til, J. (eds.): The Hungarian patient. Social opposition to an illiberal democracy. Central European University Press, Budapest, New York, 81-90.

KSH (2011): Központi Statisztikai Hivatal/Népszámlálás, www.teir.hu

Kulcsár V. (1976): A város és a falu. In: Nagy K. (szerk.): A változó falu. Gondolat Kiadó, Budapest, 7-25.

Kühn, M. (2014): Peripheralization. Theoretical concepts explaining socio-spatial inequalities. European Planning Studies, 2., 367-378. https://doi.org/10.1080/09654313.2013.862518

Ladányi J., Szelényi I., Majoros V., Virág T. (2004): A kirekesztettség változó formái. Közép- és délkelet-európai romák történeti és összehasonlító szociológiai vizsgálata. Napvilág Kiadó, Budapest

Lefebvre, H. (1991 [1974]): The Production of space. Blackwell, Oxford, Cambridge, MA

Leibert, T. (2013): The peripheralization of rural areas in post-socialist Central Europe: A case of fragmenting development? Lessons from rural Hungary. In Fischer-Tahir, A., Naumann, M. (eds.): Peripheralization: The making of spatial dependencies and social injustice. Springer Fachmedien, Wiesbaden, 101-120.

Lennert J., Kovács A. D., Farkas J. Zs.; Bódi F. (2014): Lakóhelyi szegregáció a dél-alföldi mezővárosokban. Esély, 6., 3-19.

Mihály, M. (2019a) (megjelenés alatt): Autonomy and empowerment: Social and solidarity economy initiatives and local development in peripheralised areas of Germany and Hungary. Disszertáció, Lipcsei Egyetem, Földrajzi Intézet, Lipcse

Mihály, M. (2019b): Opposing peripheralization? ACME: An International Journal for Critical Geographies, 2., 551-575. https://acme-journal.org/index.php/acme/article/view/1559 (Letöltés ideje: 2019.10.02.)

Mackenzie, C. (2014a): The importance of relational autonomy and capabilities for an ethics of vulnerability. In Mackenzie, C., Rogers, W., Dodds, S. (eds.): Vulnerability. New essays in ethics and feminist philosophy. Oxford University Press, New York, 33-59. (Studies in feminist philosophy)

Mackenzie, C. (2014b): Three dimensions of autonomy: A relational analysis. In: Veltman, A., Piper, M. (eds.): Autonomy, oppression, and gender. Oxford University Press, Oxford, New York, 15-41.

Mészáros Zs. (2013): Közösségi gazdaságfejlesztés a gyakorlatban. ACTA MEDSOC, 4, 91-106.

Mosse, D. (2005): Introduction: The ethnography of policy and practice. In: Cultivating development. An ethnography of policy and practice. Pluto Press

Nagy E., Timár J., Nagy G., Velkey G. (2015): A társadalmi-térbeli marginalizáció folyamatai a leszakadó vidéki térségekben. Tér és Társadalom, 1., 35-52. https://doi.org/10.17649/TET.29.1.2680

OTK. 1971. 1007/1971. (III. 6.) számú kormányhatározat az Országos településhálózat-fejlesztési koncepcióról. Épitésügyi Értesito”, 1971.04.07. 
Sen, A. K. (1999): Development as freedom. Oxford University Press, Oxford, New York

Soja, E. (1999): Thirdspace. Expanding the scope of the geographical imagination. In: Massey, D., Allen, J., Sarre, P. (eds.): Human geography today. Blackwell Publishers, Oxford, 260-278.

Szalai J. (2002): A társadalmi kirekesztődés egyes kérdései az ezredforduló Magyarországán. (Alapkérdések). Szociológiai Szemle, 4, 208-209.

Timár, J. (2007): Different scales of uneven development - in a (no longer) post-socialist Hungary. Treballs de la Societat Catalana de Geografia, 64., 103-128.

van Baar, H. (2012): Socio-economic mobility and neo-liberal governmentality in post-socialist Europe: Activation and the dehumanisation of the Roma. Journal of Ethnic and Migration Studies, 8., 1289-1304. https://doi.org/10.1080/1369183X.2012.689189

Váradi M. M., Virág T. (2015): A térbeli kirekesztés változó mintái vidéki terekben. The patterns of spatial exclusion in rural spaces. Szociológiai Szemle, 1., 89-113.

Váradi M. M. (2016): Értékteremtő közfoglalkoztatás periferikus vidéki térségekben. Esély, 1., 30-56.

Vidra, Zs. (2018): Hungary's punitive turn: The shift from welfare to workfare. Communist and PostCommunist Studies, 1., 73-80. https://doi.org/10.1016/j.postcomstud.2018.01.008

Vincze, E. (2014a): Romania. In: Szalai, J., Zentai, V. (eds.): Faces and causes of Roma marginalization in local contexts. https://cps.ceu.edu/sites/cps.ceu.edu/files/cps-book-faces-and-causes-romania-2014.pdf

Vincze, E. (2014b): The racialization of Roma in the 'new' Europe and the political potential of Romani women. European Journal of Women's Studies, 4., 435-442. https://doi.org/10.1177/1350506814548963

Vincze, E. (2019): Ghettoization: The production of marginal spaces of housing and the reproduction of racialized labour. In: Vincze, E., Petrovici, N., Rat, C., Picker, G. (eds.): Racialized labour in Romania. Palgrave Macmillan, Cham, 63-95. https://doi.org/10.1007/978-3-319-76273-9_3

Virág T. (2010): Kirekesztve. Falusi gettók az ország peremén. Akadémiai Kiadó, Budapest

\section{Interjúk}

Interjú_H2_I1 az Egyenlőség Alapítvány alapítója (alias Varga Anna), idősebb, nem roma nő, 2016.05.02, 60 min, jegyzetelt interjú

Interjú_H2_I4 alias Zsiga, a helyi Roma Önkormányzat vezetője, középkorú, oláhcigány férfi, 2016.05.06, 60 min, transzkriptált

Interjú_H2_I6 az Egyenlőség Alapítvány alapítója, idősebb, nem roma nő, 2017.09.29, 60 min, jegyzetelt interjú

\section{Résztvevő megfigyelés}

Terepi jegyzet_H2: 2016.05.02 és 05.07. között 6 napot töltöttem Tarnóton, ahol az Egyenlőség Alapítvány által fenntartott közösségi házban laktam. A terepen töltött 6 nap jó lehetőséget biztosított arra, hogy együtt dolgozzak és beszélgessek az alapítvány tarnóti munkatársaival, és hogy a munka utáni látogatásaim alkalmával kötetlenebb beszélgetéseken keresztül megismerjem a tarnótiak véleményét az Egyenlőség Alapítványról. A terepen töltött napjaim vázlatos összefoglalása a disszertációmban (Mihály 2019a) olvasható.

\section{Dokumentumok}

Egyenlőség Alapítvány 2016, H2_D9: Módszertani füzet a közösségfejlesztésről. A dokumentum a Norvég Civil Alap támogatásával jött létre.

H2_D5: Blogbejegyzés 2016. A blogbejegyzés, amit Varga Anna készített, kitér a képességszemlélet fontosságára a marginalizált településeket célzó fejlesztési projektek kapcsán.

H2_D26: Blogbejegyzés. 2017. Varga Anna a roma integrációról és a közmunkáról.

H2_D27: Az Egyenlőség Alapítvány pénzügyi jelentései, 2015, 2016. 